\title{
Nomenclatural checklist for Acromegalomma species (Annelida, Sabellidae), a nomen novum replacement for the junior homonym Megalomma Johansson, 1926
}

\author{
João Gil', Eijiroh Nishi ${ }^{2}$ \\ I CEAB-CSIC, Carrer d'accés a la Cala Sant Francesc, 14, 17300 Blanes (Girona), Spain / CCMAR, Univer- \\ sidade do Algarve, Campus Gambelas, 8005-139 Faro, Portugal 2 College of Education and Human Science, \\ Yokohama National University, Hodogaya Yokohama, 240-8501, Japan \\ Corresponding author: Joäo Gil (joaocfgil@gmail.com) \\ Academic editor: C. Glasby | Received 31 January 2017 | Accepted 28 April 2017 | Published 29 May 2017 \\ http://zoobank.org/8DE4D2B5-BCBE-4DA5-B831-A926DE7FD655 \\ Citation: Gil J, Nishi E (2017) Nomenclatural checklist for Acromegalomma species (Annelida, Sabellidae), a nomen \\ novum replacement for the junior homonym Megalomma Johansson, 1926. ZooKeys 677: 131-150. https://doi. \\ org/10.3897/zookeys.677.12030
}

\begin{abstract}
Acromegalomma, nomen novum, is introduced as a replacement name for the polychaete genus Megalomma Johansson, 1926 (Annelida, Sabellidae), preoccupied by Megalomma Westwood, 1842 (Insecta, Coleoptera, Carabidae). The historical background of the homonymy and a full list with 36 new combinations in the new genus are included, while two species are considered as species inquirenda.
\end{abstract}

\section{Keywords}

Fan worms, polychaete, homonymy, new substitute name, nomenclature, taxonomy

\section{Introduction}

The genus Megalomma (Annelida, Sabellidae) was established by Johansson (1926) for the usage of Branchiomma sensu Claparède (1869), based on the species Branchiomma koellikeri Claparède, 1869. However, the name Megalomma is preoccupied by Megalomma Westwood, 1842 (Insecta, Coleoptera), a well-established genus of tiger beetles from the Mascarene Islands. Megalomma Johansson, 1926 has no known available or potentially valid synonyms, for which reason, and in accordance with Article 60.3 of the ICZN (1999), it must be replaced by a new substitute name.

Copyright João Gil, Eijiroh Nishi. This is an open access article distributed under the terms of the Creative Commons Attribution License (CC BY 4.0), which permits unrestricted use, distribution, and reproduction in any medium, provided the original author and source are credited. 


\section{Historical background}

The name Megalomma was first used as a subgenus of Cicindela Linnaeus, 1758 (Insecta, Coleoptera, Carabidae) by Westwood (1842: 203), for the Mauritian species Cicindela (Megalomma) vigilans Westwood, 1842, and raised to the generic level the following year by Lacordaire (1843: 113). The genus is well established and in current use (see Moravec 2007), comprising five species from the Mascarene Islands (West Indian Ocean): $M$. fulgens W. Horn, 1892; M. janaki Moravec, 2007; M. oculatum (Fabricius, 1799); M. pierreorum Deuve, 2000; and M. viridulum (Quensel in Schönherr, 1806), which includes as a synonym the type species of the genus, M. vigilans (Westwood, 1842).

A second genus Megalomma was created by Smith (1873: 405) in Hymenoptera (Insecta), to include three new species from Brazil: Megalomma politum Smith, 1873, M. elegans Smith, 1873, and M. nigriceps Smith, 1873. Later Schulz (1906: 200) pointed that it was a junior homonym of Megalomma Westwood, 1842 and replaced it by the new name Megistommum Schulz, 1906.

In polychaetes, the name Megalomma was first used by Johansson (1926: 10), as a replacement name for Branchiomma sensu Claparède (1869), based on a misinterpretation of Claparède's work. While discussing the validity of the name Dasychone introduced by Sars (1862) for sabellids with eyes on their radioles, Claparède (1869) stated that Kölliker (1858) had already used the name Branchiomma for the same group, to include Amphitrite bombyx Dalyell, 1853 (renamed as Branchiomma dalyellii Kölliker, 1858). However, instead of synonymizing the junior Dasychone into Branchiomma, Claparède (1869: 162) tried to retain both by redefining the genus Branchiomma, with the following justification:

Quoi quil en soit, le nom de Dasychone a pris place dans la science, et celui de Branchiomma est à peu près oublié. Je pense pourtant pouvoir ressusciter celui-ci, en tenant compte des scrupules de M. Sars, et sans proscrire le nom de Dasychone. Dans son mémoire sur le genre Branchiomma, M. Kölliker décrit en outre de la Dasychone Bombyx une autre espèce qu'il n'a étudiée que d'une manière très-cursive, il est vrai, dans le golfe de Naples, et qui est caractérisée par des yeux à l'extrémité des branchies. Cette espèce que j'ai retrouvée n'est point une Dasychone. Elle pourra rester dorénavant l'espèce-type du genre Branchiomma.

Hence, Claparède (1869) attempted to transfer Amphitrite bombyx Dalyell, 1853 to Dasychone (see Claparède 1869: 168), while making reference to a short comment by Kölliker (1858: 536) where he recorded that he had observed, but not named nor described in detail, an additional sabellid from Naples with eight compound eyes near the tips of the radioles:

Schon im Jahre 1842 kam mir in Neapel ein kleiner Kopfkiemer unter die Augen, der an seinen Kiemen 8 zusammengesetzte Sehorgane trug. Leider war es mir damals, da 
ich gerade mit der Verfolgung der Entwicklung der Cephalopoden beschäftigt war, nicht möglich, diese interessante Annelide, von der ich ohnehin nur Ein Individuum erhalten hatte, näher zu verfolgen, und unterliess ich es daher, etwas über dieselbe zu veröffentlichen.

Consequently, Claparède described this species as Branchiomma koellikeri [original spelling köllikeri corrected here to koellikeri according to Article 32.5.2.1 of the ICZN (1999)], based on the specimens collected by him at the Gulf of Naples, citing (Claparède 1869: 164):

Je doute à peine que cette espèce soit la même que M. Kölliker a eue sous les yeux. Elle n'est en effet point rare dans le golfe de Naples. M. Kölliker n’indique, il est vrai, que huit filaments branchiaux, tandis que jen ai compté jusqu'à trente-deux. Mais cela peut ne tenir qu'à une différence d'àge.

This leaves little doubt that Claparède considered his new species Branchiomma koellikeri to be the same species observed previously by Kölliker from Naples and, moreover, that he proposed B. koellikeri as the type of his emendation of Kölliker's genus with the sentence (Claparède 1869: 162): "Elle pourra rester dorénavant l'espècetype du genre Branchiomma."

Apparently Claparède's intention was simply to redefine the genus Branchiomma to restrict it to the unnamed Kölliker species (= B. koellikeri Claparède, 1869, the intended new type species of the redefined genus), as can be inferred by the fact that he wrote "Genre Branchiomma Koellkr. char. em." (Claparède 1869: 162).

However, Johansson (1926: 10) considered erroneously that Claparède was formally establishing a new genus, an interpretation that was followed by other authors (e.g. Hartman 1959, Day 1967, Fauchald 1977).

In this way, Johansson (1926: 10) argued that the generic name Branchiomma sensu Claparède (1869), used for Branchiomma koellikeri, could not be accepted, as it was already preoccupied by Kölliker (1858) for the species Amphitrite bombyx Dalyell, 1853. A new replacement name was thus necessary, and Johansson introduced for the third time in Zoology the name Megalomma, emphasizing the large compound eyes of the genus (Johansson 1926: 10):

Als Claparède 1869 für seine Art Köllikeri die Gattung Branchiomma bildete, war der Name schon präokkupiert. Die Gattung Branchiomma Claparède muss also einen neuen Namen erhalten. Ich schlage Megalomma vor, welcher Name wie Branchiomma auf die grossen zusammengesetzen Augen dieser Gattung hindedeutet, doch ohne ihren Charakter als Branchialaugen hervorzuheben [...].

However, and as stated above, the name Megalomma Johansson, 1926 is itself preoccupied by Megalomma Westwood, 1842, and a replacement name is necessary. The name Acromegalomma, nomen novum is here proposed to accomplish this need. 


\section{Chronology of the genus-level name Megalomma}

1842. Westwood (p. 203): Cincidella (Megalomma) new subgenus (Insecta, Coleoptera, Carabidae), for Cicindella (Megalomma) vigilans Westwood, 1842.

1843. Lacordaire (p. 113): Megalomma raised to generic level.

1858. Kölliker (p. 537): Branchiomma new genus (Annelida, Sabellidae), for Amphitrite bombyx Dalyell, 1853 (renamed as Branchiomma dalyellii Kölliker, 1858).

1869. Claparède (p. 162-163): Branchiomma redefined (Annelida, Sabellidae), for Branchiomma koellikeri Claparède, 1869. Amphitrite bombyx Dalyell, 1853 assigned to Dasychone Sars, 1862.

1873. Smith (p. 405): Megalomma new genus (Insecta, Hymenoptera, Crabronidae), for Megalomma politum Smith, 1873, M. elegans Smith, 1873, and M. nigriceps Smith, 1873.

1906. Schulz (p. 200): Megistommum new name (Insecta, Hymenoptera, Crabronidae), replacement name for Megalomma Smith, 1873.

1926. Johansson (p. 10): Megalomma new genus (Annelida, Sabellidae), to include Branchiomma sensu Claparède, 1869 (not Branchiomma Kölliker, 1858).

Present study. Acromegalomma new name (Annelida, Sabellidae), replacement name for Megalomma Johansson, 1926.

\section{Material and methods}

To establish the list of new combinations in Acromegalomma new name a list of valid Megalomma species was compiled based on WoRMS (Bellan 2008), and updated with Tovar-Hernández and Carrera-Parra (2011), Mikac et al. (2013), Capa and Murray (2015) and Giangrande et al. (2015). Synonymies were obtained from Tovar-Hernández and Carrera-Parra (2011). The type of synonymy and its author are provided inside square brackets, following the synonym.

Each new combination is accompanied by the reference of the original description, synonymies, type locality of the species and remarks, when necessary. Type locality is based on the original description, except where indicated. Geolocations of type localities are derived from the original descriptions, being considered an "original geolocation" when the authors provided the coordinates, or "estimated geolocation", when estimated using Google Earth (www.google.com/earth) from the general geographic limits described by the authors. All geolocations were converted to decimal degrees.

The whereabouts of type material of the new combinations were summarised by Tovar-Hernández and Carrera-Parra (2011) and following publications describing new species (Mikac et al. 2013, Capa and Murray 2015, Giangrande et al. 2015).

While the gender of Megalomma and Acromegalomma new name is neuter, some names in Megalomma had incorrect endings and needed to be emended. Following Article 31.2 of the ICZN (1999), the names of the new combinations and the species inquirenda were herein revised to assure they agreed in gender with the generic name 
with which they are combined. Original names with incorrect endings are indicated with the remark "[sic]" following the specific epithet. Endings corrected herein are: carunculatum for carunculata, inflatum for inflata, interruptum for interrupta, jubatum for jubata, and longoventrale for longoventralis.

\section{Systematics}

Order Sabellida Latreille, 1825

Family Sabellidae Latreille, 1825

\section{Genus Acromegalomma, nomen novum}

Branchiomma [not Kölliker, 1858] — Claparède 1869: 162-163.

Megalomma [junior homonym, not Westwood, 1842] — Johansson 1926: 9-10; Johansson 1927: 130; Perkins 1984: 351-352; Fitzhugh 1989: 76; Knight-Jones 1997: 314; Fitzhugh 2003: 107; Tovar-Hernández and Salazar-Vallejo 2008: 1953-1954; Giangrande and Licciano 2008: 208; Capa and Murray 2009: 204205; Tovar-Hernández and Carrera-Parra 2011: 14-15; Mikac et al. 2013: 1514; Capa et al. 2014: 27-28; Giangrande et al. 2015: 522-523.

Type species. The type species of the new genus is Branchiomma koellikeri Claparède, 1869 (junior synonym of Sabella lanigera Grube, 1846), according to recommendation 60A of the ICZN (1999). Type by monotypy, established by Johansson (1926).

Type material. Following his principle of basing observations and descriptions only on live organisms Édouard Claparède did not designate type material or deposit specimens in museums or collections (Fauchald 1989). However, Knight-Jones (1997) refers the existence of a type of Branchiomma koellikeri Claparède, 1869 deposited at the Zoological Museum of Berlin (currently the Museum für Naturkunde Berlin), with the reference number ZMB 6387. Tovar-Hernández and Carrera-Parra (2011) refer this specimen as being a syntype. Although the designation of a lectotype for $B$. koellikeri is desirable, it is out of the scope of the present work.

Etymology. The name of the new genus is composed by combining the Greek terms for acro, meaning "tip end" or "extremity of a body", mega, meaning "big" or "large", and the suffix -omma, a noun meaning "eye", and referring to the big compound eyes located on the radiolar subdistal region, typical of the genus.

Gender. Neuter.

Remarks. The publication date of the genus Megalomma Johansson should be considered as "1926". It was generally accepted as being "1927" until Tovar-Hernández and Salazar-Vallejo (2008) pointed out that the name had been introduced in a previous publication by the same author, referring the date as "1925". In fact, the last page of this publication states "Tryckt den 5 november 1925" ("Printed the 5 November 1925") and in the following line "Uppsala 1925. Almquist \& Wiksells Boktryckeri-A.- 
$B . "$ This date is also present in existing reprints of the paper. However, the bounded volume comprising the article provides the publication date as "Häfte 2 inneh. A N:o 6-12, [...] utkom den 5 juni 1926" "Booklet 2 cont. A No. 6-12, [...] published 5 June 1926"). This booklet includes article 7A by Johansson, where the name Megalomma is introduced for polychaetes. Hence, the work was printed in 5 November 1925, but published only in the following year, on 5 June 1926.

The genus Acromegalomma, nomen novum is represented by 36 valid species, all of them new combinations.

List of new combinations in the genus Acromegalomma new name Acromegalomma acrophthalmos (Grube, 1878) comb. $\mathbf{n}$.

Sabella acrophthalmos Grube 1878: vii, 258-259.

Type locality. Singapore $\left(1.25^{\circ}, 103.85^{\circ}\right.$; estimated geolocation $)$ or Philippines $\left(12.22^{\circ}, 121.77^{\circ}\right.$; estimated geolocation).

Remarks. The type locality of the species was first stated as being "probably Singapore" ("wahrscheinlich von Singapore"; Grube 1878: vii), and later in the same publication, as "Philippines" ("Von den Philippinen"; Grube 1878: 258).

Acromegalomma adriaticum (Giangrande, Caruso, Mikac \& Licciano, 2015) comb. nov.

Megalomma adriaticum Giangrande et al. 2015: 526-528, figs 6-8.

Type locality. Brindisi, Italy, South Adriatic Sea $\left(40.65^{\circ}, 17.95^{\circ}\right.$; original geolocation).

Acromegalomma bioculatum (Ehlers, 1887) comb. $\mathbf{n}$.

Branchiomma bioculatum Ehlers 1887: 260-263, plate 53 figs 1-9.

Type locality. West of Dry Tortugas, Straits of Florida $\left(24.6181^{\circ},-83.0517^{\circ}\right.$; original geolocation).

Acromegalomma carunculatum (Tovar-Hernández \& Salazar-Vallejo, 2008) comb. n.

Megalomma carunculata [sic] Tovar-Hernández and Salazar-Vallejo 2008: 1957-1961, figs 1-2. 
Type locality. Punta Manzanillo, Acapulco, Guerrero, Mexican Pacific (16.842 $-99.910^{\circ}$; estimated geolocation).

Acromegalomma cinctum (Fitzhugh, 2003) comb. n.

Megalomma cinctum Fitzhugh 2003: 108-116, figs 1-10, 14C.

Type locality. Hungtou Yu (Orchid Island), northern coastline, about $1 \mathrm{~km}$ east of Langtao Village, Taiwan, Pacific Ocean $\left(22.0794^{\circ}, 121.5369^{\circ}\right.$; original geolocation).

Acromegalomma circumspectum (Moore, 1923) comb. n.

Branchiomma circumspectum Moore 1923: 239-241, plate XVIII figs 41-42.

Type locality. Between S. $35^{\circ} \mathrm{W}, 3.5$ miles $(5.6 \mathrm{~km})$ and $\mathrm{S} .43^{\circ} \mathrm{W}, 5.2$ miles $(8.4 \mathrm{~km})$ off Brockway Point, Santa Rosa Island, Channel Islands, California, Pacific coast of the USA $\left(34.02^{\circ},-120.22^{\circ}\right.$; estimated geolocation).

Acromegalomma claparedei (Gravier, 1906) comb. n.

Branchiomma claparedei Gravier 1906: 39-40.

Type locality. Syntypes collected at the reef of Marabout $\left(11.611^{\circ}, 43.132^{\circ}\right.$; estimated geolocation), at Djibouti Bay, and the "Grand Récif" $\left(11.736^{\circ}, 43.235^{\circ}\right.$; estimated geolocation), Moucha Islands, both at the Gulf of Tadjoura, Gulf of Aden, Indian Ocean.

Remarks. Gravier introduced the name Branchiomma claparedei as new twice, first in 1906 (Gravier 1906: 39) and again in 1908 (Gravier 1908b: 91). This caused some confusion, inducing some authors in error, by considering the correct publication date as being 1908, while overlooking the smaller 1906 publication (e.g. Tovar-Hernández and CarreraParra 2011). The correct publication date is therefore "1906" (see also Wehe and Fiege 2002).

Acromegalomma coloratum (Chamberlin, 1919) comb. $\mathrm{n}$.

Potamilla colorata Chamberlin 1919b: 21.

Type locality. Laguna Beach, California, Pacific coast of the USA $\left(33.542^{\circ},-117.786^{\circ}\right.$; estimated geolocation).

Synonym. Potamilla clara Chamberlin 1919b: 20 [subjective synonymy by TovarHernández and Carrera-Parra (2011)]. 
Acromegalomma fauchaldi (Giangrande, Licciano \& Gambi, 2007) comb. n. Megalomma fauchaldi Giangrande et al. 2007: 46-47, fig. 2.

Type locality. Lagoon side of Carrie Bow Cay, Belize, Caribbean Sea (16.803 $-88.085^{\circ}$; estimated geolocation).

Acromegalomma georgiense (Tovar-Hernández \& Carrera-Parra, 2011) comb. n.

Megalomma georgiense Tovar-Hernández and Carrera-Parra 2011: 56-58, fig. 26A-L.

Type locality. Off Georgia, Atlantic coast of the USA $\left(30.95^{\circ},-79.9667^{\circ}\right.$; original geolocation).

Acromegalomma gesae (Knight-Jones, 1997) comb. n.

Megalomma gesae Knight-Jones 1997: 318-319, fig. 3.

Type locality. La Herradura, Estero Jaltepeque, El Salvador, Pacific Ocean (13.303 , $-88.902^{\circ}$; estimated geolocation).

Synonym. Potamilla bioculata Hartmann-Schröder 1959: 175-176, figs 183-188 [objective synonymy by Knight-Jones (1997); Megalomma gesae is a new name for $P$. bioculata].

Acromegalomma heterops (Perkins, 1984) comb. n.

Megalomma heterops Perkins 1984: 359-363, figs 42-43.

Type locality. Hutchinson Island, Florida, Atlantic Ocean $\left(27.345^{\circ},-80.2133^{\circ}\right.$; original geolocation).

Acromegalomma inflatum (Capa \& Murray, 2009) comb. n.

Megalomma inflata [sic] Capa and Murray 2009: 217-218, figs 4G-H, 5D, 11.

Type locality. Southeast of Bate Bay, New South Wales, Australia $\left(-34.0667^{\circ}\right.$, $151.2167^{\circ}$; original geolocation). 
Acromegalomma interruptum (Capa \& Murray, 2009) comb. n.

Megalomma interrupta [sic] Capa and Murray 2009: 210-212, figs 2J-M, 4E-F, 5B, 7, 8.

Type locality. One Tree Island, Queensland, Australia (-23.5 $152.0833^{\circ}$; original geolocation).

Acromegalomma jubatum (Capa \& Murray, 2015) comb. n.

Megalomma jubata [sic] Capa and Murray 2015: 128-130, fig. 12.

Type locality. MacGillivray Reef, Lizard Island, Queensland, Australia (-14.6569 ${ }^{\circ}$, $145.4947^{\circ}$; original geolocation).

Acromegalomma kaikourense (Knight-Jones, 1997) comb. n.

Megalomma kaikourense Knight-Jones 1997: 320-321, fig. 5.

Type locality. Point Kean near Kaikoura, east coast of South Island, New Zealand $\left(-42.425^{\circ}, 173.715^{\circ}\right.$; estimated geolocation).

Acromegalomma lanigerum (Grube, 1846) comb. $\mathrm{n}$.

Sabella lanigera Grube 1846: 51-53, plate II fig. 1.

Type locality. Unknown.

Synonyms. Branchiomma köllikeri Claparède 1869: 163-164, plate XXII fig. 4 [subjective synonymy by Knight-Jones (1997)]. Branchiomma vesiculosum neapolitana Claparède 1869: 164-166, plate XXII fig. 5 [subjective synonymy by Giangrande and Licciano (2008)].

Remarks. The species was described based on a single specimen (T-ZMB 136) deposited at the Zoological Museum of Berlin (currently the Museum für Naturkunde Berlin), from an unknown location (Grube 1846: 51).

Acromegalomma lobiferum (Ehlers, 1887) comb. n.

Branchiomma lobiferum Ehlers 1887: 254-259, plate 53, figs 10-15 (figure 15 numbered as 16 in plate 53).

Type locality. Key West, Florida, Gulf of Mexico $\left(24.54^{\circ},-81.80^{\circ}\right.$; estimated geolocation). 
Acromegalomma longoventrale (Giangrande, Caruso, Mikac \& Licciano, 2015) comb. n.

Megalomma longoventralis [sic] Giangrande et al. 2015: 524-526, figs 3-5.

Type locality. Rovinj, coastal station near the Island Banjole, Croatia, North Adriatic Sea $\left(45.095250^{\circ}, 13.619283^{\circ}\right.$; original geolocation).

Acromegalomma messapicum (Giangrande \& Licciano, 2008) comb. $\mathbf{n}$.

Megalomma messapicum Giangrande and Licciano 2008: 213-214, figs 5G-H, 6.

Type locality. Brindisi, Italy, Adriatic Sea $\left(40.65^{\circ}, 17.96^{\circ}\right.$; estimated geolocation).

Acromegalomma miyukiae (Nishi, 1998) comb. n.

Megalomma miyukiae Nishi 1998: 53-54, figs 1-4.

Type locality. Ao Tang Khen, Phuket, Thailand, Andaman Sea $\left(7.8185^{\circ}, 98.4144^{\circ}\right.$; estimated geolocation).

Acromegalomma modestum (Quatrefages, 1866) comb. n.

Sabella modesta Quatrefages 1866: 451-452.

Type locality. Lima, Peru, Pacific Ocean $\left(-12.07^{\circ},-77.15^{\circ}\right.$; estimated geolocation).

Synonym. Potamilla anophthalma Hartmann-Schröder 1960: 41-43, figs 89-91 [subjective synonymy by Knight-Jones (1997)].

Acromegalomma multioculatum (Fitzhugh, 2002) comb. n.

Megalomma multioculatum Fitzhugh 2002: 401-405, figs 34A-C, 35A-B, 36A-D, 37.

Type locality. Thailand, Andaman Sea (08.5, $98.1^{\circ}$; original geolocation).

Acromegalomma mushaense (Gravier, 1906) comb. n.

Branchiomma mushaensis [sic] Gravier 1906: 40-41. 
Type locality. "Grand Récif” (11.736, $43.235^{\circ}$; estimated geolocation), Moucha Islands, Gulf of Tadjoura, Gulf of Aden, Indian Ocean.

Remarks. As in the case of Branchiomma claparedei explained above, Gravier introduced the name Branchiomma mushaensis [sic] as new twice, first in 1906 (Gravier 1906: 40) and again in 1908 (Gravier 1908b: 94). This incurred some authors into error (e.g. Tovar-Hernández and Carrera-Parra 2011). The correct publication date is "1906" (see also Wehe and Fiege 2002).

Acromegalomma nechamae (Knight-Jones, 1997) comb. n.

Megalomma nechamae Knight-Jones 1997: 319-320, fig. 4.

Type locality. El Bilaiyim (= Ghor Blayim) lagoons, Sinai Peninsula, Gulf of Suez $\left(28.55^{\circ}, 33.24^{\circ}\right.$; estimated geolocation).

Acromegalomma pacifici (Grube \& Örsted in Grube, 1859) comb. n.

Sabella pacifici Grube and Örsted in Grube 1859: 113.

Type locality. Punta Arenas, Gulf of Nicoya, Costa Rica $\left(9.976^{\circ},-84.852^{\circ}\right.$; estimated geolocation).

Synonym. Pseudopotamilla panamica Chamberlin 1919a: 268-269, plate 3 fig. 8 [subjective synonymy by Knight-Jones (1997)].

Remarks. The authorship of the species is here considered as "Grube \& Örsted in Grube, 1859", according to Salazar-Vallejo and Eibye-Jacobsen (2012: 1398). The authorship appears clearly referred twice in the original publication as "Gr. Örsd." (Grube 1859: 113, 120).

Acromegalomma perkinsi (Tovar-Hernández \& Salazar-Vallejo, 2006) comb. n.

Megalomma perkinsi Tovar-Hernández and Salazar-Vallejo 2006: 43-45, fig. 11.

Type locality. Cape Lookout, North Carolina, Atlantic coast of the USA (34.62 , $-76.54^{\circ}$; estimated geolocation).

Acromegalomma phyllisae (Capa \& Murray, 2009) comb. n.

Megalomma phyllisae Capa and Murray 2009: 205-208, figs 2A-E, 3, 4A-B, 5A.

Type locality. Off Townsend Point, Corner Inlet, Victoria, Australia $\left(-38.8^{\circ}, 146.55^{\circ}\right.$; original geolocation). 
Acromegalomma pigmentum (Reish, 1963) comb. $\mathrm{n}$.

Megalomma pigmentum Reish 1963: 430-431, figs 15, 16A-I.

Type locality. Bahía de San Quintín, Baja California, Mexico, Pacific Ocean (30.456 , $-115.958^{\circ}$; estimated geolocation).

Synonym. Megalomma monoculata [sic] Hartmann-Schröder 1965: 273-276, figs 276-278 [subjective synonymy by Knight-Jones (1997)].

Acromegalomma pseudogesae (Mikac, Giangrande \& Licciano, 2013) comb. n.

Megalomma pseudogesae Mikac et al. 2013: 1514-1515, fig. 3.

Type locality. 13 nautical miles off the coast of the Istrian Peninsula, Croatia, Gulf of Venice, Northern Adriatic Sea $\left(45.2833^{\circ}, 13.2667^{\circ}\right.$; original geolocation).

Acromegalomma quadrioculatum (Willey, 1905) comb. n.

Branchiomma quadrioculatum Willey 1905: 307, plate VII figs 168-169.

Type locality. Aripu (= Arippu) Coral Reef, Sri Lanka, Gulf of Manaar, Indian Ocean $\left(08.78^{\circ}, 79.87^{\circ}\right.$; estimated geolocation).

Acromegalomma roulei (Gravier, 1908) comb. nov.

Branchiomma roulei Gravier 1907: 526 (nomen nudum); Gravier 1908a: 44.

Type locality. Payta (= Paita), Peru, Pacific Ocean $\left(-5.083^{\circ},-81.111^{\circ}\right.$, estimated geolocation).

Acromegalomma splendidum (Moore, 1905) comb. n.

Pseudopotamilla splendida Moore 1905: 564-566, plate XXXVII figs 23-27.

Type locality. Kasaan Bay, center of Round Island, S. 10d W., 0.4 miles, Clarence Strait, Prince of Wales Island, Alexander Archipelago, SE Alaska, North Pacific Ocean $\left(55.51^{\circ},-132.39^{\circ}\right.$; estimated geolocation).

Synonyms. Pseudopotamilla anoculata Moore 1905: 566-568, plate XXXVII figs 28-33 [subjective synonymy by Hartman (1959)]. Branchiomma disparoculatum 
Treadwell 1914: 223-224, plate 12 figs 44-46 [subjective synonymy by Hartman (1956)]. Branchiomma burrardum Berkeley 1930: 71, fig. 1 [subjective synonymy by Knight-Jones (1997)].

Acromegalomma suspiciens (Ehlers, 1904) comb. $\mathrm{n}$.

Branchiomma suspiciens Ehlers 1904: 62-63, plate IX figs 1-6.

Type locality. French Pass, between D'Urville Island and north end of South Island, New Zealand $\left(-40.922^{\circ}, 173.837^{\circ}\right.$; estimated geolocation).

Acromegalomma trioculatum (Reish, 1968) comb. n.

Megalomma trioculatum Reish 1968: 226-228, fig. 5 (1-10).

Type locality. Lagoon side of Engebi (= Enjebi) Island, Enewetak (= Eniwetok) Atoll, Ralik Chain, Marshall Islands, Pacific Ocean (11.658 $8^{\circ} 162.235^{\circ}$; estimated geolocation).

Acromegalomma vesiculosum (Montagu, 1813) comb. $\mathrm{n}$.

Amphitrite vesiculosa Montagu 1813: 19-20, plate V fig. 1.

Type locality. Original type locality at Kingsbridge Estuary, Devon, England (50.263 , $-03.765^{\circ}$; estimated geolocation). Neotype designated by Knight-Jones (1997: 314) from St. Anthony, Cornwall, England $\left(50.15^{\circ},-5.2667^{\circ}\right.$; original geolocation misplaced, corrected here to $\left.50.152^{\circ},-5.006^{\circ}\right)$.

\section{Species inquirenda}

Megalomma vigilans (Claparède, 1870) [unreplaced junior secondary homonym]

Branchiomma vigilans Claparède 1870: 501-503, plate XIV fig. 3.

Type locality. Gulf of Naples, Mediterranean Sea ( $40.7^{\circ}, 14.3^{\circ}$; estimated geolocation).

Remarks. Branchiomma vigilans was described on the basis of three specimens from the Gulf of Naples, all of them found with their muddy tubes inserted among the dorsal chaetae of individuals of Aphrodita aculeata Linnaeus, 1758 (Claparède 1870). Afterwards the species was recorded on only a couple of occasions in the Western Mediterranean, first by Marion (1876), in the Gulf of Marseille and from 60-65 m 
(no habitat details), and later by Soulier (1903), who observed about ten specimens collected off Séte (Gulf of Aigues-Mortes) among the chaetae of $A$. aculeata specimens. Rioja (1923) attributed an empty sandy tube found among the dorsal chaetae of an A. aculeata collected in the region of Valencia to this species, but this record is very dubious, as not only was the worm not present but also the nature of the tube differed from that described by Claparède (1870). Moreover, no type material of B. vigilans is known to exist (Knight-Jones 1997, Giangrande and Licciano 2008, Tovar-Hernández and Carrera-Parra 2011) as Claparède normally did not deposit specimens in museums or collections (Fauchald 1989).

The species was transferred to Megalomma by Hartman (1959: 550), creating a junior secondary homonym of the tiger beetle Megalomma vigilans (Westwood, 1842) (see above), and has since remained a poorly known but valid taxon (Knight-Jones 1997, Tovar-Hernández and Salazar-Vallejo 2008). Giangrande and Licciano (2008) considered the species as being quite rare, probably due to its peculiar habitat, and in spite of stating that its real status needed confirmation, they also observed that it was likely a valid species. However, the species was subsequently omitted from the discussions on new Mediterranean species of Megalomma by Mikac et al. (2013) and Giangrande et al. (2015). The most recent reference to the species seems to be by Tovar-Hernández and Carrera-Parra (2011: 5), who wrote:

Megalomma vigilans (Claparede, 1870) was originally found as an epibiont of the sea mouse Aphrodita aculeata Linnaeus, 1758, in the Mediterranean Sea, however, no new records of this association exist. [...] In the case of $\mathrm{M}$. vigilans, the description is poor, the type is lost and there are no additional records.

The described habitat of Megalomma vigilans is unusual, and there are no references of similar cases in the family Sabellidae. It is possible that the habitat is an artefact resulting from the collection process, and that the presence of the species on individuals of Aphrodita aculeata was the consequence of the rough treatment and mixing suffered by the biological material collected by grabs and trawls, or even during the processing of the samples. So, the presence of $M$. vigilans on $A$. aculeata could be a post-collection phenomenon, and not the natural habitat of the worm. It is difficult or even impossible to know if the records by Marion (1876) and Soulier (1903) refer to the same species as that collected and described by Claparède (1870) without studying the material, if still existing. There is a possibility that $M$. vigilans is not as uncommon as it seems, but that for some reason it has not been collected or recognised. For the time being, M. vigilans is here considered as a species inquirenda.

\section{Megalomma pacificum Johansson, 1927}

Megalomma pacifica [sic] Johansson 1927: 130-131, textfig. 15.11.

Type locality. Syntypes collected at Aranuka Island, outside the coral reef $\left(0.14^{\circ}\right.$, $173.56^{\circ}$; estimated geolocation), and Tapeteuea (= Tabiteuea) Island, inside the lagoon $\left(-1.5^{\circ}, 175.0^{\circ}\right.$; estimated geolocation), both at Gilbert Islands, Kiribati, Pacific Ocean. 
Remarks. According to Fitzhugh (2002), Megalomma pacificum Johansson, 1927 probably belongs to the genus Demonax Kinberg, 1867 (a name recently replaced by Parasabella Bush, 1905 due to homonymy; see Tovar-Hernández and Harris 2010). The fact that the holotype has dried out (Knight-Jones 1997) and that the species has a remote type locality have likely prevented a formal redescription. The species was not included in the Parasabella species list given by Tovar-Hernández and Harris (2010), but its possible inclusion in Parasabella has been implicitly accepted by subsequent authors (Capa and Murray 2009, Tovar-Hernández and Carrera-Parra 2011).

\section{Acknowledgements}

The authors would like to express their deep gratitude to the generous help of Miguel Ángel Alonso Zarazaga (MNCN, Madrid, Spain), who replied to our questions concerning some nomenclatural details and corrected the endings of the specific epithets of the new combinations, so they agreed in gender with the new generic name, and Andrew S. Y. Mackie (National Museum Wales, Cardiff, UK) for having found the time to make a critical reading of the first draft of the manuscript and correct its English while on vacations. Geoff Read and María Ana Tovar-Hernández are thanked for their very detailed revisions of the first version, which have improved the manuscript considerably, and Chris Glasby for his help as Editor. This work was financially supported by the European Community's Seventh Framework Programme (FP7/2007-2013), through the Assemble Grant Agreement no. 227799-ASSEMBLE to the project "Biodiversity of Annelida Polychaeta in the Ria Formosa coastal lagoon: a baseline study", awarded to J.G. and developed at the CCMAR, University of Algarve (Faro, Portugal).

\section{References}

Bellan G (2008) Megalomma Johansson, 1926. In: Read G, Fauchald K (Eds) World Polychaeta database. http://www.marinespecies.org/polychaeta/aphia.php?p=taxdetails\&id=129536 [2016-06-08]

Berkeley E (1930) Polychaetous annelids from the Nanaimo District. Part 5. Ammocharidae to Myzostomidae. Contributions to Canadian Biology and Fisheries 6: 65-77. http://doi. org/10.1139/f31-005

Bush KJ (1905) Tubiculous annelids of the tribes Sabellides and Serpulides from the Pacific Ocean. Harriman Alaska Expedition 12: 169-346. http://doi.org/10.5962/bhl.title.16297

Capa M, Murray A (2009) Review of the genus Megalomma (Polychaeta: Sabellidae) in Australia with description of three new species, new records and notes on certain features with phylogenetic implications. Records of the Australian Museum 61(2-3): 201-224. http:// doi.org/10.3853/j.0067-1975.61.2009.1529

Capa M, Murray A (2015) A taxonomic guide to the fanworms (Sabellidae, Annelida) of Lizard Island, Great Barrier Reef, Australia, including new species and new records. Zootaxa 4019(1): 98-167. http://doi.org/10.11646/zootaxa.4019.1.8 
Capa M, Giangrande A, Nogueira JMM, Tovar-Hernández MA (2014) Sabellidae Latreille, 1825. In: Westheide W, Purschke G (Eds) The Handbook of Zoology. De Gruyter, Berlin, 42 pp. http://www.degruyter.com/view/Zoology/bp_029147-6-62

Chamberlin RV (1919a) Pacific coast Polychaeta collected by Alexander Agassiz. Bulletin of the Museum of Comparative Zoology 63(6): 251-270. http://www.biodiversitylibrary.org/ page/30574684

Chamberlin RV (1919b) New polychaetous annelids from Laguna Beach, California. Pomona College Journal of Entomology and Zoology 11(1): 1-23. http://biodiversitylibrary.org/ page/ 12263520

Claparède E (1869) Les annélides chétopodes du Golfe de Naples. Ordre IIme. Annélides sédentaires (Aud. et Edw.). Mémoires de la Société de Physique et d'Histoire Naturelle de Genève 20(1): 1-225. http://doi.org/10.5962/bhl.title.105355

Claparède E (1870) Les annélides chétopodes du Golfe de Naples. Supplément. Mémoires de la Société de Physique et d'Histoire Naturelle de Genève 20(2): 365-542. http://biodiversitylibrary.org/page/2094031

Dalyell JG (1853) The powers of the Creator displayed in the Creation; or, Observations on life amidst the various forms of the humbler tribes of animated nature: with practical comments and illustrations. John van Voorst, Volume 2, London, 359 pp. http://dx.doi. org/10.5962/bhl.title.10022

Day JH (1967) A monograph on the Polychaeta of Southern Africa. Part I. Errantia. Part II. Sedentaria. British Museum (Natural History), London 656: 1-878. http://dx.doi. org/10.5962/bhl.title.8596

Deuve T (2000) Description de Megalomma pierreorum n. sp., nouvelle Cicindèle de l'Île de la Réunion (Coleoptera, Cicindelidae). Bulletin de la Société Entomologique de France 104(5): 409-411.

Ehlers E (1887) Reports on the results of dredging, under the direction of L. F. Pourtalès, during the years 1868-1870, and of Alexander Agassiz, in the Gulf of Mexico (1877-78), and in the Caribbean Sea (1878-79), in the U.S. Coast Survey Steamer "Blake". XXXI. Report on the annelids. Memoirs of the Museum of Comparative Zoology at Harvard College 15: 1-335. http://doi.org/10.5962/bhl.title.65639

Ehlers E (1904) Neuseeländische Anneliden. Abhandlungen der Königlichen Gesellschaft der Wissenschaften zu Göttingen Mathematisch-Physikalische Klasse, Neue Folge 3: 1-80. http://biodiversitylibrary.org/page/46755553

Fabricius JC (1799) Index Alphabeticus. Supplementum Entomologiae Systematicae, Ordinees, Genera et Species Continens. Proft et Storch, Kopenhagen, 53 pp. http://doi.org/10.5962/ bhl.title. 123559

Fauchald K (1977) The polychaete worms. Definitions and keys to the orders, families and genera. Natural History Museum of Los Angeles County, Science Series 18: 1-188. http:// hdl.handle.net/10088/3435

Fauchald K (1989) The Second Annual Riser Lecture: eclectism and the study of polychaetes. Proceedings of the Biological Society of Washington 102(3): 742-752. http://biodiversitylibrary.org/page/34551126 
Fitzhugh K (1989) A systematic revision of the Sabellidae-Caobangiidae-Sabellongidae complex (Annelida: Polychaeta). Bulletin of the American Museum of Natural History 192: 1-104. http://hdl.handle.net/2246/881

Fitzhugh K (2002) Fan worm polychaetes (Sabellidae: Sabellinae) collected during the ThaiDanish BIOSHELF Project. Phuket Marine Biological Center Special Publication 24: 353-424.

Fitzhugh K (2003) A new species of Megalomma Johansson, 1927 (Polychaeta: Sabellidae: Sabellinae) from Taiwan with comments on sabellid dorsal lip classification. Zoological Studies 42(1): 106-134. http://zoolstud.sinica.edu.tw/Journals/42.1/106.pdf

Giangrande A, Licciano M (2008) Revision of the species of Megalomma (Polychaeta: Sabellidae) from the Mediterranean Sea, with the description of $M$. messapicum n. sp. Italian Journal of Zoology 75(2): 207-217. http://doi.org/10.1080/11250000801913124

Giangrande A, Licciano M, Gambi MC (2007) A collection of Sabellidae (Polychaeta) from Carrie Bow Cay (Belize, western Caribbean Sea) with the description of two species. Zootaxa 1650: 41-53. http://www.mapress.com/j/zt/article/view/4192

Giangrande A, Caruso LPG, Mikac B, Licciano M (2015) The genus Megalomma (Annelida: Sabellidae) in the Mediterranean Sea, with description of two new species from Italian and Croatian coasts. Italian Journal of Zoology 82(4): 521-534. http://doi.org/10.1080/1125 0003.2015.1072251

Gravier C (1906) Sur les annélides polychètes de la Mer Rouge (Sabellides). Bulletin du Muséum d'Histoire Naturelle, Paris 12(1): 33-43. http://biodiversitylibrary.org/page/5021208

Gravier C (1907) Sur les annélides polychètes rapportés par M. le Dr. Rivet, de Payta (Pérou). Bulletin du Muséum d'Histoire Naturelle, Paris 13(7): 525-530. http://biodiversitylibrary. org/page/5042880

Gravier C (1908a) Sur les annélides polychètes rapportés par M. le Dr Rivet, de Payta (Pérou) [Suite]. Bulletin du Muséum d'Histoire Naturelle, Paris 14 (1): 40-44. http://biodiversitylibrary.org/page/5030891

Gravier C (1908b) Contribution à l'étude des annélides polychètes de la Mer Rouge (suite). Nouvelles Archives du Muséum d'Histoire Naturelle, Paris, 4e Série 10: 67-168. http:// biodiversitylibrary.org/page/36098324

Grube AE (1846) Beschreibungen neuer oder weniger bekannter Anneliden. Erster Beitrag: Sabella Lucullana delle Chiaie, S. luxuriosa Gr. nov. sp., S. lanigera Gr. nov. spec., S. Josephinae Risso, S. penicillus Sav., S. pavonina Sav. Archiv für Naturgeschichte, Berlin 12 (1): 45-59. http://biodiversitylibrary.org/page/13704785

Grube AE (1859) Annulata Örstediana. Enumeratio Annulatorum, quae in itinere per Indiam occidentalem et Americam centralem annis 1845-1848 suscepto legit cl. A.S. Örsted, adjectis speciebus nonnullis a cl. H. Kröyero in itinere ad Americam meridionalem collectis. (Slutning). Videnskabelige Meddelelser fra den naturhistoriske Forening i Kjöbenhavn 1858: 105-120. http://doi.org/10.5962/bhl.title.46255

Grube AE (1878) Annulata Semperiana. Beiträge zur Kenntniss der Annelidenfauna der Philippinen nach den von Herrn Prof. Semper mitgebrachten Sammlungen. Mémoires de l'Académie Impériale des Sciences de St.-Pétersbourg., VIIe Série 25 (8): 1-300. http:// doi.org/10.5962/bhl.title.85345 
Hartman O (1956) Polychaetous annelids erected by Treadwell, 1891 to 1948, together with a brief chronology. Bulletin of the American Museum of Natural History 109(2): 239-310. http://hdl.handle.net/2246/1145

Hartman O (1959) Catalogue of the polychaetous annelids of the world. Allan Hancock Foundation Publications, Occasional Paper 23: 1-628.

Hartmann-Schröder G (1959) Zur Ökologie der Polychaeten des Mangrove-Estero-Gebietes von El Salvador. Beitrage zur Neotropischen Fauna 1(2): 69-183. http://doi. org/10.1080/01650525909380612

Hartmann-Schröder G (1960) Zur Polychaeten-Fauna von Peru. Beiträge zur neotropischen Fauna 2(1): 1-44. http://doi.org/10.1080/01650526009380621

Hartmann-Schröder G (1965) Die Polychaeten des Sublitorals. In: Hartmann-Schröder G, Hartmann G. Zur Kenntnis des Sublitorals der chilenischen Küste unter besonderer Berücksichtigung der Polychaeten und Ostracoden. (Mit bemerkungen über den Einfluss sauerstoffarmer Strömungen auf die Besiedlung von marien Sedimenten.). Mitteilungen aus dem Hamburgischen zoologischen Museum und Institut 62: 59-305.

Horn W (1892) Fünf Dekaden neuer Cicindeleten. Deutsche Entomologische Zeitschrift 36(1): 65-92. http://biodiversitylibrary.org/page/33128450

International Commission of Zoological Nomenclature (1999) International Code of Zoological Nomenclature. Fourth Edition. London: The International Trust for Zoological Nomenclature. http://doi.org/10.5962/bhl.title.50608

Johansson KE (1926) Bemerkungen über die Kinberg'schen Arten der Familien Hermellidae und Sabellidae. Arkiv för Zoologi 18A(7): 1-28. http://www.marinespecies.org/aphia. php?p=sourcedetails\&id=50543

Johansson KE (1927) Beiträge zur Kenntnis der Polychaeten-Familien Hermellidae Sabellidae und Serpulidae. Zoologiska Bidrag från Uppsala 11: 1-184.

Kinberg JGH (1867) Annulata nova. Öfversigt af Kongliga Vetenskaps-Akademiens Förhandlingar, Stockholm 23(9): 337-357. http://biodiversitylibrary.org/page/32287795

Knight-Jones P (1997) Two new species of Megalomma (Sabellidae) from Sinai and New Zealand with redescriptions of some types and a new genus. Bulletin of Marine Science 60(2): 313-323. http://www.ingentaconnect.com/contentone/umrsmas/bullmar/1997/00000060/00000002/ $\operatorname{art} 00013$

Kölliker H (1858) Ueber Kopfkiemer mit Augen an den Kiemen. Zeitschrift für Wissenschaftliche Zoologie, Leipzig 9(4): 536-541. http://biodiversitylibrary.org/page/13863875

Lacordaire T (1843) Révision de la famille des Cicindélides (Cicindelidae) de l'ordre des Coléoptères, accompagnée de la création de quelques genres nouveaux. Mémoires de la Société Royale des Sciences de Liége 1: 85-120. http://biodiversitylibrary.org/page/16181642

Latreille PA (1825) Familles naturelles du règne animal, exposées succinctement et dans un ordre analytique avec l'indication de leurs genres. J.-B. Baillière, Paris, 570 pp. http://doi. org/10.5962/bhl.title.34914

Linnaeus C (1758) Systema Naturae per Regna Tria Naturae, Secundum Classes, Ordines, Genera, Species, cum characteribus, differentiis, synonymis, locis. Tomus I. Editio Decima, Reformata. Laurentii Salvii, Stockholm, 824 pp. http://doi.org/10.5962/bhl.title.542 
Marion AF (1876) Draguages profonds au large de Marseille (Juillet-Octobre 1875). Note préliminaire. Revue des Sciences Naturelles 4: 469-477. http://biodiversitylibrary.org/ page/ 14526635

Mikac B, Giangrande A, Licciano M (2013) Sabellidae and Fabriciidae (Polychaeta) of the Adriatic Sea with particular retrospect to the Northern Adriatic and the description of two new species. Journal of the Biological Association of the United Kingdom 93(6): 1511-1524. http://doi. org/10.1017/S0025315412001993

Montagu G (1813) Descriptions of several new or rare animals, principally marine, discovered on the south coast of Devonshire. Transactions of the Linnean Society of London 11(1): 1-26. http://doi.org/10.1111/j.1096-3642.1813.tb00035.x

Moore JP (1905) Five new species of Pseudopotamilla from the Pacific coast of North America. Proceedings of the Academy of Natural Sciences of Philadelphia 57: 555-569. http://biodiversitylibrary.org/page/6331971

Moore JP (1923) The polychaetous annelids dredged by the U.S.S. "Albatross" off the coast of southern California in 1904. IV. Spionidae to Sabellariidae. Proceedings of the Academy of Natural Sciences of Philadelphia 75: 179-259. http://doi.org/10.5962/bhl.title.12425

Moravec J (2007) New or rare Madagascar tiger beetles - 11. Revision within Mascarenian Cicindelidae: Megalomma janaki sp. nov., a new species from Mauritius (Coleoptera. Cicindelidae). Folia Heyrovskyana, Series A 15: 27-37.

Nishi E (1998) A new species of Megalomma (Annelida: Polychaeta: Sabellidae) from Phuket, Thailand. Pacific Science 52(1): 53-60. http://hdl.handle.net/10125/1558

Perkins TH (1984) Revision of Demonax Kinberg, Hypsicomus Grube, and Notaulax Tauber, with a review of Megalomma Johansson from Florida (Polychaeta: Sabellidae). Proceedings of the Biological Society of Washington 97(2): 285-368. http://biodiversitylibrary.org/ page/34553607

Quatrefages A (1866) Histoire naturelle des annelés marins et d'eau douce. Annélides et géphyriens. Tome second. Deuxième partie. Librarie Encyclopédique de Roret, Paris, 337-794. http://doi.org/10.5962/bhl.title.122818

Reish DJ (1963) A quantitative study of the benthic polychaetous annelids of Bahía de San Quintín, Baja California. Pacific Naturalist 3(14): 399-436. http://aquaticcommons.org/ id/eprint/11222

Reish DJ (1968) The polychaetous annelids of the Marshall Islands. Pacific Science 22(2): 208-231. http://hdl.handle.net/10125/6824

Rioja E (1923) Estudio sistemático de las especies ibéricas del suborden Sabelliformia. Trabajos del Museo Nacional de Ciencias Naturales. Serie Zoológica 48: 3-144. http://simurg.bibliotecas.csic.es/viewer/image/CSIC000082883/1/

Salazar-Vallejo SI, Eibye-Jacobsen D (2012) Annulata örstediana: publication dates, composition and annoted taxonomic list, with some comments on Hemipodus (Polychaeta: Glyceridae). Revista de Biología Tropical 60(3): 1391-1402. http://dx.doi.org/10.15517/rbt. v60i3.1815

Sars M (1862) Foredrag om de ved Norges Kyster forekommende Arter af den Linnéiske Annelideslægt Sabella. Forhandlinger I Videnskabs-Selskabet I Christiania 1861: 116-133. http://www.marinespecies.org/aphia.php?p=sourcedetails\&id=51726 
Schönherr CJ (1806) Synonymia Insectorum, oder: Versuch einer Synonymie Aller bischer bekannten Insecten; nach Fabricii Systema Eleutheratorum geordnet. Mit Berichtigungen und Anmerkungen, wie auch Beschreibungen neuer Arten und illuminirten Kupfern 1(1): 1-294. http://doi.org/10.5962/bhl.title.66107

Schulz WA (1906) Spolia Hymenopterologica. Junfermannschen Buchhandlung, Paderborn, 356 pp. http://doi.org/10.5962/bhl.title.59757

Smith F (1873) Descriptions of new species of fossorial Hymenoptera in the collection of the British Museum [continued from p. 300]. Annals and Magazine of Natural History, Fourth Series 12(71): 402-415. http://doi.org/10.1080/00222937308680789

Soulier A (1903) Revision des annélides de la région de Cette (2e fascicule). Académie des Sciences et Lettres de Montpellier. Mémoires de la Section des Sciences. 2e Série 3: 193-278.

Tovar-Hernández MA, Salazar-Vallejo SI (2006) Sabellids (Polychaeta: Sabellidae) from the Grand Caribbean. Zoological Studies 45(1): 24-66. http://zoolstud.sinica.edu.tw/Journals/45.1/24.pdf

Tovar-Hernández MA, Salazar-Vallejo SI (2008) Caruncle in Megalomma Johansson, 1925 (Polychaeta: Sabellidae) and the description of a new species from the Eastern Tropical Pacific. Journal of Natural History 42(29): 1951-1973. http://doi. org/10.1080/00222930802140186

Tovar-Hernández MA, Harris LH (2010) Parasabella Bush, 1905, replacement name for the polychaete genus Demonax Kinberg, 1867 (Annelida, Polychaeta, Sabellidae). ZooKeys 60: 13-19. http://doi.org/10.3897/zookeys.60.547

Tovar-Hernández MA, Carrera-Parra LF (2011) Megalomma Johansson, 1925 (Polychaeta: Sabellidae) from America and other world-wide localities, and phylogenetic relationships within the genus. Zootaxa 2861: 1-71. http://www.mapress.com/zootaxa/list/2011/2861.html

Treadwell AL (1914) Polychaetous annelids of the Pacific Coast in the collections of the Zoological Museum of the University of California. University of California Publications in Zoology 13(8): 175-234. http://biodiversitylibrary.org/page/34806017

Wehe T, Fiege D (2002) Annotated checklist of the polychaete species of the seas surrounding the Arabian Peninsula: Red Sea, Gulf of Aden, Arabian Sea, Gulf of Oman, Arabian Gulf. Fauna of Arabia 19: 7-238. http://www.senckenberg.de/files/content/forschung/ abteilung/aquazool/mev2/wehe_\%26_fiege.pdf

Westwood JO (1842) Insectorum Novorum Centuria. Decadis secundae, ex ordine Coleopterum, Synopsis. Annals and Magazine of Natural History 8(50): 203-205. http://doi. org/10.1080/03745484109442753

Willey A (1905) Report on the Polychaeta collected by Professor Herdman, at Ceylon, in 1902. Report to the Government of Ceylon on the Pearl Oyster Fisheries of the Gulf of Manaar by W.A. Herdman, with supplementary reports upon the Marine Biology of Ceylon, by Other Naturalists. Part IV. Supplementary Reports 30: 243-324. http://biodiversitylibrary.org/page/1936112 